\title{
Perbedaan Derajat Keasaman (pH) Saliva Antara Perokok dan Bukan Perokok pada Siswa SMA PGRI 1 Padang
}

\author{
Muhammad Zakwan Qalbi ${ }^{1}$, Miftah Irramah ${ }^{2}$, Asterina $^{3}$
}

\begin{abstract}
Abstrak
Rongga mulut merupakan bagian yang paling awal dari tubuh manusia yang terpapar secara langsung terhadap asap rokok. Saliva adalah kelenjar yang terdapat di rongga mulut yang berperan sebagai pertahanan mukosa rongga mulut melalui kapasitas buffer yang terdapat didalamnya. Derajat keasaman $(\mathrm{pH})$ saliva diketahui sebagai nilai yang dapat diukur untuk menggambarkan kapasitas buffer saliva. Tujuan penelitian ini adalah menentukan perbedaan $\mathrm{pH}$ saliva antara perokok dan bukan perokok. Penelitian ini merupakan studi analitik komparatif dengan desain cross sectional yang dilakukan dari September 2017 sampai Januari 2018 di SMA PGRI 1 Kota Padang. Sebanyak 70 orang untuk masing-masing kelompok perokok dan bukan perokok dari siswa SMA PGRI 1 Kota Padang dipilih secara Simple Random Sampling. Status merokok diukur dengan wawancara kebiasaan merokok, sedangkan nilai $\mathrm{pH}$ diukur dengan $\mathrm{pH}$ meter. Data yang diperoleh diuji secara statistik dengan uji MannWhitney. Hasil penelitian menunjukan rerata $\mathrm{pH}$ saliva perokok 6,239 $\pm 0,296$ dan bukan perokok 6,923 $\pm 0,2925$. Analisis data yang dilakukan memperoleh nilai signifikasi $p<0,05$ yang menunjukan perbedaan yang bermakna antara $\mathrm{pH}$ saliva perokok dan bukan perokok. Berdasarkan hasil penelitian dapat disimpulkan $\mathrm{pH}$ saliva perokok lebih rendah dibanding $\mathrm{pH}$ bukan perokok.
\end{abstract}

Kata kunci: status merokok, derajat keasaman, saliva

\begin{abstract}
The oral cavity is the beginning part of human body which is exposed directly towards smokes. Saliva glands are the glands located in the oral cavity with the roles as mucous's defense through buffer mechanism inside. The acidity level $(\mathrm{pH})$ of saliva is known as a measurable value to describe the buffer capacity. The objective of this study was to determine the difference of acidity level of saliva between smokers and non smokers. This experiment was a comparative analytics experiment using cross sectional design that has been done from September 2017 until on January 2018 at SMA PGRI Padang. There were70 subjects for each smokers and non smokers group of students from SMA PGRI 1 Padang that was choosen randomly by using Simple Random Sampling. The smoking status was measured by interviewing the smoking habit, the $\mathrm{pH}$ value is measured by using $\mathrm{pH}$ meter. The data were collected and had been tested statiscally by using Mann-Whitney test. The result of this experiment shows that the amount of average acidity level $(\mathrm{pH})$ of smokers's saliva is 6,239 $\pm 0,296$ and non smokers's was 6,923 $\pm 0,2925$. The data analytic had been done and resulted significant value $p<0,05$ that show the meaningful difference between smokers and non smokers. Based on the result of this experiment is concluded that the acidity level $(\mathrm{pH})$ of saliva in smokers is lower than non smokers.
\end{abstract}

Keywords: smoking status, acidity level $(\mathrm{pH})$, saliva

Affiliasi penulis: 1. Prodi Kedokteran Fakultas Kedokteran Universitas Andalas Padang (FK Unand), 2. Bagian Fisika FK Unand, 3. Bagian Kimia FK Unand
Korespondensi: Muhammad Zakwan Qalbi, Email: qolbimuhammad65@gmail.com,Telp: 082383476296 


\section{PENDAHULUAN}

Perokok didefinisikan oleh WHO (World Health Organization) sebagai seseorang yang pada saat dilakukan survey sedang menghisap produk tembakau apapun, baik itu dilakukan setiap hari ataupun kadangkadang. Perokok dibagi atas perokok harian (daily smoker) yaitu perokok yang setidaknya merokok satu batang per hari dan perokok sesekali (occasional smoker)yaitu perokok yang menghisap rokok tetapi tidak rutin setiap hari. ${ }^{1}$

Rokok mengandung banyak komponen zat yang berbahaya bagi kesehatan tubuh manusia, satu batang rokok setidaknya terdiri dari tiga jenis tembakau, tembakau memiliki 2.500 komponen yang sudah teridentifikasi. Tembakau pada rokok memiliki sekitar 4.800 komponen kimia yang terkandung di dalamnya, diantaranya adalah nikotin, nitrogen, karbondioksida, pestisida, tar dan benzene. ${ }^{2}$

Pada rongga mulut terdapat saliva sebagai salah satu mekanisme pertahanan tubuh yang disekresikan oleh tiga pasang kelenjar utama yang mengandung 99,5\% $\mathrm{H}_{2} \mathrm{O}$ dan $0,5 \%$ elektrolit dan protein. ${ }^{3}$ Saliva menyekresikan dua jenis cairan utama yaitu sekresi serosa yang mengandung ptialin sebagai enzim yang mencerna makanan dan mukus yang mengandung musin sebagai pelindung permukaan mukosa rongga mulut. ${ }^{4}$

Saliva memiliki $\mathrm{pH}$ pada kisaran 6.5-7.4 yang memperlancar kerja enzim pencernaan seperti ptialin, selain itu saliva mengandung immunoglobulin (lg)A yang bekerja sebagai respon imun humoral pada mukosa rongga mulut dihasilkan oleh sel B yang berfungsi untuk mencegah perlengketan bakteri ataupun virus ke rongga mulut, ketika seseorang terpapar asap rokok secara aktif, akan menurunkan antibodi yang terkandung pada saliva tersebut, sehingga berdampak terhadap turunnya kemampuan saliva sebagai pertahanan rongga mulut, sehingga, bakteri anaerob mudah berkembang pada mukosa mulut dan mengakibatkan rongga mulut mudah terinfeksi. $^{5}$

Saliva disekresikan dengan kecepatan laju aliran saliva $20 \mathrm{ml} / \mathrm{jam}$ pada saat istirahat, hal-hal yang menyebabkan perubahan pada kecepatan laju aliran saliva salah satunya adalah paparan asap rokok terhadap kelenjar saliva. Perubahan laju aliran saliva pada perokok akan mengalami penurunan sehingga mempengaruhi $\mathrm{pH}$ saliva pada perokok, penurunan laju inilah yang menyebabkan turunnya bikarbonat yang ada pada saliva sebagai kapasitas buffer, dalam suasana lingkungan rongga mulut yang asam sesuai dengan tempat berkembangnya bakteri asidofilik yang berujung pada infeksi. ${ }^{6}$

Penurunan $\mathrm{pH}$ asam pada saliva sangat mempengaruhi stabilitas saliva dalam melindungi mukosa mulut sehingga perlengketan bakteri pada mukosa rongga mulut akan mudah terjadi. Perlengketan bakteri pada mukosa ini akan memudahkan terjadinya infeksi yang bisa menimbulkan berbagai penyakit pada rongga mulut yaitu periodontal disease, radang gusi, serta munculnya lesi khas pada mukosa rongga mulut. ${ }^{7}$

Wabah tembakau merupakan ancaman besar yang sangat berperan dalam mempengaruhi derajat kesehatan masyarakat, WHO 2017 mendapatkan lebih dari 7 juta orang pertahun meninggal karena tembakau. Ada satu miliar perokok yang ada di dunia, $80 \%$ berasal dari negara berpenghasilan rendah sampai menengah, termasuk Indonesia. ${ }^{8}$

Riset Kesehatan Dasar ( RISKESDAS ) tahun 2013, mendapatkan prevalensi merokok penduduk Indonesia usia 15 tahun ke atas terus mengalami peningkatan dari tahun 2007 yaitu 34,2 \% ke tahun 2013 menjadi 36,3\%, dimana perokok laki-laki masih lebih banyak daripada perempuan yaitu berada di angka $64,9 \%$ dan perempuan di angka 2,1\%. Proporsi perokok setiap hari di wilayah Sumatera Barat sekitar $26,4 \%$ berada pada peringkat ke lima setelah Kepulauan Riau, Jawa Barat, Nusa Tenggara Barat dan Bangka Belitung. ${ }^{9}$

Penelitian yang dilakukan oleh Sabri et al terhadap pelajar di tiga sekolah di kota Padang pada tahun 2012, ditemukan lebih dari seperempat pelajar pernah merokok dan semuanya adalah laki laki. Semakin longgarnya akses untuk merokok bagi para pelajar membuat angka peningkatan konsumsi rokok di Indonesia semakin meningkat dari tahun ke tahun. Meningkatnya jumlah perokok di Indonesia juga disebabkan oleh lebih dininya usia mulai merokok pada remaja. $^{10}$ 
Tahun 2012 Dwiastuti N melakukan penelitian terhadap mahasiswa teknik Universitas Muhammadiyah Surakarta, didapatkan $\mathrm{pH}$ saliva pada perokok lebih asam dibanding $\mathrm{pH}$ saliva bukan perokok. ${ }^{11}$

SMA PGRI 1 merupakan SMA swasta di Kota Padang yang terletak di tengah kota, dan memiliki akses yang mudah untuk menuju lokasi. Hasil observasi yang telah dilakukan pada bulan September 2017 terhadap 10 orang pelajar dari semua tingkatan kelas di SMA PGRI 1 Kota Padang, didapatkan 7 dar 10 siswa adalah perokok aktif, angka ini menunjukkan besarnya jumlah perokok yang ada pada siswa PGRI 1 Kota Padang. Berdasarkan uraian diatas, peneliti tertarik untuk mencoba meneliti "Perbedaan $\mathrm{pH}$ Saliva Perokok dan Bukan Perokok pada Siswa SMA PGRI 1 Kota Padang".

\section{METODE}

Jenis penelitian yang dilakukan adalah analitik komparatif numerik tidak berpasangan dengan menggunakan rancangan cross sectional (potong lintang). Penelitian ini dilakukan setelah mendapat kelayakan etik (ethical clearance) dari Komisi Etik Penelitian Fakultas Kedokteran Universitas Andalas dengan nomor surat 443/KEP/FK/2017.

Populasi penelitian ini adalah siswa laki -laki SMA PGRI 1 Padang. Responden penelitian ini adalah 140 orang siswa SMA PGRI 1 Padang yang bisa membuka mulut dan tidak mengkonsumsi makanan dua jam sebelum pemeriksaan. Penelitian ini dibagi kedalam 2 kelompok sampel yaitu sebanyak 70 orang perokok dan 70 orang bukan perokok.

Penelitian diawali dengan meminta persetujuan dari responden yang akan menjadi sampel penelitian, setelah mendapatkan persetujuan responden akan diminta untuk mengisi kuisioner kebiasaan merokok dan diwawancarai untuk mengelompokkan responden pada kelompok perokok dan bukan perokok. Pada saat wawancara juga ditanyakan responden tidak mengkonsumsi makanan 2 jam sebelumnya.

Setelah didapatkan status merokok sampel, responden akan diminta untuk mencuci mulut dengan menggunakan air, instrumen yang akan digunakan pada penelitian ini adalah kom, sarung tangan dan $\mathrm{pH}$ meter. Responden diminta untuk memberikan saliva sebanyak $\pm 5 \mathrm{ml}$ pad kom yang telah disediakan.

Pengukuran $\mathrm{pH}$ saliva akan dihitung segera setelah saliva responden didapatkan dengan cara merendamkan elektroda $\mathrm{pH}$ meter kedalam cairan saliva selama 10 detik, lalu indikator $\mathrm{pH}$ terlihat pada layar $\mathrm{pH}$ meter dan selanjutnya akan dicatat $\mathrm{pH}$ saliva sampel berdasarkan status merokok.

\section{HASIL}

Tabel 1. Distribusi subjek penelitian

\begin{tabular}{lcc}
\hline \multicolumn{1}{c}{ Karakteristik Subjek } & Frekuensi & Persentase \\
\hline Perokok & 70 & \\
Kelas X & 23 & 32,8 \\
Kelas XI & 30 & 42,8 \\
Kelas XII & 19 & 27,14 \\
Bukan Perokok & 70 & \\
Kelas X & 28 & 40 \\
Kelas XI & 27 & 38,5 \\
Kelas XII & 13 & 18,5 \\
\hline
\end{tabular}

Tabel 1 menunjukan jumlah subjek dari setiap kelompok. Total kedua kelompok adalah 140 orang (100\%). Kelompok siswa yang merokok diperoleh 70 sampel yang terdiri dari kelas $X(32,8 \%)$, kelas $\mathrm{XI}$ (42,8\%) dan kelas XII (27,14\%)sedangkan untuk kelompok mahasiswa yang tidak merokok diperoleh 70 sampel, kelas X (40\%), kelas XI(38,5\%), dan kelas XII $(18,5 \%)$.

Tabel 2. $\mathrm{pH}$ saliva sampel

\begin{tabular}{lllll}
\hline \multirow{2}{*}{$\begin{array}{l}\text { Status Kebiasaan } \\
\text { Merokok }\end{array}$} & \multicolumn{4}{c}{ pH Saliva } \\
\cline { 2 - 5 } & \multicolumn{2}{c}{ Asam } & \multicolumn{3}{c}{ Normal } \\
\cline { 2 - 5 } & 5 & $\%$ & $\Sigma$ & $\%$ \\
\hline Perokok & 58 & 82,9 & 12 & 17,1 \\
Bukan Perokok & 7 & 10 & 63 & 90 \\
\hline
\end{tabular}

Tabel 2 memperlihatkan distribusi nilai $\mathrm{pH}$ untuk tiap kelompok, dari data diperoleh perokok lebih dominan memiliki $\mathrm{pH}$ saliva yang asam $(<6,5)$ yaitu sebanyak $82,9 \%$, sedangkan bukan perokok memiliki $\mathrm{pH}$ saliva normal $(6,5-7,4)$ yaitu $90 \%$, 
Tabel 3. Analisis perbedaan $\mathrm{pH}$ saliva pada status merokok

\begin{tabular}{llc}
\hline Variabel & pH Saliva & Nilai Signifikasi \\
\hline Perokok & $6,239 \pm 0,296$ & 0,000 \\
& & \\
Bukan Perokok & $6,923 \pm 0,292$ & \\
\hline
\end{tabular}

Hasil uji normalitas yang dilakukan pada data penelitian dengan uji Saphiro Wilk menunjukkan bahwa data berdistribusi tidak normal dengan nilai signifikansi $<0,05$. Selanjutnya, data diuji dengan uji Mann Withney. Analisis untuk mengetahui perbedaan antara nilai $\mathrm{pH}$ saliva dengan kedua variabel. Hasil uji analisis kedua variabel didapatkan $p=0,000$, Hal ini menunjukkan terdapat perbedaan yang bermakna antara $\mathrm{pH}$ saliva perokok dan bukan perokok

\section{PEMBAHASAN}

Dalam keadaan fisiologis $\mathrm{pH}$ saliva berkisar antara 6,5-7,4. Hal ini dipengaruhi oleh laju aliran dan kapasitas buffer saliva. Konsentrasi bikarbonat mempengaruhi kapasitas buffer dalam saliva. Laju aliran saliva yang menurun, kapasitas buffer juga menurun. Penurunan dua faktor tersebut berpengaruh dalam pengaturan $\mathrm{pH}$ saliva dalam melindungi rongga mulut. $^{12}$

Hasil penelitian ini diperoleh rerata $\mathrm{pH}$ saliva pada perokok sebesar 6,2, hal ini menunjukkan terdapatnya pengaruh status kebiasaan merokok terhadap perubahan $\mathrm{pH}$ saliva. Data dalam Tabel 2 memperlihatkan hasil pengukuran $\mathrm{pH}$ pada perokok lebih banyak memiliki nilai $\mathrm{pH}$ asam yaitu sebesar $82,9 \%$ responden perokok. Hasil ini sesuai dengan penelitian yang telah dilakukan oleh Dwiastuti $\mathrm{N}$ di Surakarta yang juga mendapatkan nilai $\mathrm{pH}$ saliva asam. $^{11}$

Penelitian yang berbeda didapatkan oleh Alweheb tahun 2005 yang mendapatkan nilai pH saliva pada perokok dalam batas normal, hal ini diduga karena adanya pengaruh konsumsi jumlah besar rokok yang berperan dalam perubahan laju aliran saliva. ${ }^{13}$

Keadaan asam pada lingkungan rongga mulut yang disebabkan oleh pengaruh merokok akan menyebabkan bakteri asidofilik yang ada pada rongga mulut berkembang, keadaan ini semakin diperparah dengan hasil asam dari metabolisme bakteri tersebut, dalam keadaan asam ini infeksi pada rongga mulut akan mudah terjadi. Komponen toksik didalam rokok juga dapat mengiritasi jaringan lunak rongga mulut, dan dapat berujung pada keganasan rongga mulut. ${ }^{14}$

Tabel 3 memperlihatkan hubungan status kebiasaan merokok terhadap $\mathrm{pH}$ saliva, didapatkan $\mathrm{pH}$ saliva responden perokok lebih rendah dibandingkan dengan $\mathrm{pH}$ saliva bukan perokok. Pada Tabel 3 didapatkan nilai signifikasi $p<0,05$ hal ini dapat disimpulkan bahwa terdapat perbedan yang bermakna antara $\mathrm{pH}$ saliva perokok dan bukan perokok, hasil ini sesuai dengan penelitian yang telah dilakukan oleh Trudgill tahun 1998 yang mendapatkan penurunan konsentrasi bikarbonat didalam saliva pada subjek perokok sehingga menyebabkan lebih rendahnya derajat keasaman $(\mathrm{pH})$ saliva perokok dibandingkan dengan $\mathrm{pH}$ saliva non perokok. ${ }^{15}$

Hasil yang sama didapatkan oleh Syifa N yang melihat pengaruh merokok terhadap penurunan $\mathrm{pH}$ saliva yang memperoleh hasil yang bermakna, konsumsi rokok yang sering dan dalam jangka waktu yang lama sangat mempengaruhi kapasitas buffer didalam rongga mulut yaitu $\mathrm{pH}$ saliva. ${ }^{16}$

Penelitian Pramesta BD (2013) dan Dwiastuti N (2012) yang melihat pengaruh perubahan $\mathrm{pH}$ saliva pada perokok dan mendapatkan hasil nilai $\mathrm{pH}$ saliva prokok lebih rendah dibandingkan $\mathrm{pH}$ saliva bukan perokok. Kedua penelitian ini juga mendapatkan perbedaan yang signifikan antara $\mathrm{pH}$ saliva perokok dan bukan perokok. ${ }^{11,17}$

Hasil yang berbeda didapatkan oleh Alweheb 2005 yang melihat efek rokok terhadap karies gigi dan faktor saliva, didapatkan hasil yang tidak signifikan antara $\mathrm{pH}$ saliva perokok dengan rata-rata $\mathrm{pH}$ saliva 7,32 lebih tinggi dibandingkan $\mathrm{pH}$ saliva bukan perokok 7,24. Alweheb menyimpulkan perbedaan $\mathrm{pH}$ saliva perokok akan lebih nyata tampak pada perokok dengan jumlah konsumsi rokok yang besar dan intensitas waktu yang relatif lebih lama. ${ }^{13}$ Hasil penelitian ini memperlihatkan kesesuaian dengan teori yang telah ada yaitu laju aliran saliva pada perokok yang menurun sangat berpengaruh pada nilai $\mathrm{pH}$ saliva. Penurunan laju aliran saliva menyebabkan komponen anorganik juga akan menurun, sehingga 
mengakibatkan turunnya $\mathrm{pH}$ saliva. ${ }^{18}$ Perubahan $\mathrm{pH}$ saliva dapat mempengaruhi fungsi saliva. Fungsi saliva yang paling berpengaruh yaitu dalam hal kebersihan rongga mulut dan sebagai antimikroba. ${ }^{4}$

Penelitian yang serupa juga pernah dilakukan oleh Sari tahun 2011 yang melihat kekuatan hubungan merokok terhadap penurunan $\mathrm{pH}$ saliva, hasil yang didapatkan oleh peneliti dengan menggunakan uji kolerasi Lambda diperoleh nilai kolerasi $(r)$ sebesar 0,036. Interpretasi hasil uji kolerasi tersebut dapat disimpulkan bahwa terdapat hubungan yang lemah antara kebiasaan merokok dengan penurunan $\mathrm{pH}$ saliva, hasil korelasi yang lemah ini dapat dihubungkan dengan faktor perancu yang tidak bisa dikendalikan, yaitu diet atau konsumsi makanan responden sebelum dilakukan pemeriksaan $\mathrm{pH}$ saliva. $^{19}$

Berdasarkan analisis statistik terdapat perbedaan yang bermakna antara $\mathrm{pH}$ saliva perokok dan bukan perokok, dan pada Tabel 3 didapatkan $\mathrm{pH}$ saliva pada perokok lebih rendah dibanding pada bukan perokok, dengan demikian maka dapat dinyatakan bahwa hipotesis penelitian diterima.

\section{SIMPULAN}

$\mathrm{pH}$ saliva perokok lebih rendah dibandingkan $\mathrm{pH}$ saliva bukan perokok dan terdapat perbedaan yang bermakna antara $\mathrm{pH}$ saliva perokok dan bukan perokok.

\section{DAFTAR PUSTAKA}

1. World Health Organization (WHO). Guidelines for controlling and monitoring the tobacco epidemic. Part II. Monitoring the tobacco epidemic. Chapter 8. Monitoring tobacco use. Geneva: WHO; 1998.

2. Tirtosastro S, Murdiyati AS. Kandungan kimia tembakau dan rokok. Buletin TanamanTembakau, Serat \& Minyak Industri. April 20102;(1):33-43.

3. Sherwood L. Fisiologi manusia dari sel ke sistem. Edisi ke-6. Nella Yesdelita, penterjemah. Jakarta: EGC; 2012.hlm.625-50.

4. Guyton AC, Hall JE. Textbook of medical physiology. Edisi ke-12. Widjajakusumah, penterjemah. Jakarta: Elsevier; 2011.hlm.839-40.
5. Kinane DF, Radvar M. The effect of smoking and antimicrobial periodontal therapy. J Perio. 1997;68:467-72.

6. Pejcic A, Obradovic R, Kesic L, Kojovic D. Smoking and periodontal disease. A Review. Medicine and Biology. 2007;14(2):53-9.

7. Aditama TY. Rokok dan kesehatan. Jakarta: UI Press; 1997.hlm.17-25.

8. World Health Organization (WHO). Tobacco: key facts. (diunduh September 2017). Tersedia dari: http://www.who.Int/mediacentre/factsheets/fs339/e n/

9. Badan Penelitian dan Pengembangan Kesehatan Kementrian Kesehatan RI. Riset kesehatan dasar. Jakarta: Kementrian Kesehatan RI; 201: .21-3.

10. Sabri YS, Khairsyaf O, Awal R. Profil merokok pada pelajar di tiga SMP di Kota Padang. Jurnal Kedokteran Andalas. 2015;4(3):12-3.

11. Dwiastuti N. Perbedaan $\mathrm{pH}$ saliva antara perokok dan bukan perokok pada mahasiswa teknik mesin Universitas Muhammadiyah Surakarta (skripsi). Surakarta: Fakultas Kedokteran Universitas Muhammadiyah Surakarta. 2012.hlm.61-2.

12. Kanwar A, Sah K, Grover N, Chandra S. Long term effect oftobacco on resting whole mouth salivary flow rate and $\mathrm{pH}: \mathrm{An}$ institusional based comparative study. European Journal of General Dentistry. Desember 2013;2(3):296-9.

13. Alweheb MA. Smoking and its relation to caries experience and salivary lactobacili count. J Cool Dentistry. 2005;17(1):92.

14. Bergstrom. A 10-year prospective study of tobacco smoking and periodontalhealth. J Periodontol. 2000;71:1338-47.

15. Trudgill. Impact of smoking cessation on salivary function in healthy volunteers. US National Library of Medicine National Institues of Health. 1998 Juni;33(6):1216-28.

16. Syifa N. Peran rokok terhadap $\mathrm{pH}$ saliva (skripsi). Jakarta: Fakultas Kedokteran UIN Jakarta; 2013.hIm.26-7.

17. Pramesta BD. Deteksi derajat keasaman $(\mathrm{pH})$ saliva pada pria perokok dan non-perokok (skripsi). Jakarta: Fakultas Kedokteran UIN; 2014.hlm.31-2 
18. Almeida PD, Gregio AM, Machado MA. Saliva composition and function: A comprehensive review. The Journal of Contamporary Dental Practice. 2008;9(3):1-2.
19. Sari IP. Pengaruh saliva pada perokok (skripsi). Mataram: Fakultas Kedokteran Universitas Mataram; 2011.hlm.7-8 